\title{
Katarzyna BEDNARSKA
}

Uniwersytet Łódzki

katarzyna.bednarska@uni.lodz.pl

\section{AUTHOR'S NEOLOGISMS IN \\ GEORGE R. R. MARTIN'S A GAME OF THRONES AND THEIR POLISH AND SLOVENE TRANSLATIONS}

Elements of fantasy have been present in literature since its beginnings, but the fantasy genre in its modern sense is less than 200 years old. It gained its biggest popularity in the 1950s and 1960s, when J. R. R. Tolkien, C. S. Lewis and Ursula K. Le Guin published their novels (Tolkien: Middle-earth novels - The Hobbit, The Lord of the Rings and The Silmarillion, Lewis: Chronicles of Narnia, Le Guin: novels about Earthsea). Those milestones helped fantasy to enter the mainstream (Yolen 2001: vii-viii). The popularity of the genre even increased in the 21st century, on one hand thanks to fantasy film adaptations such as Peter Jackson's trilogy The Lord of the Rings, and the Harry Potter films, and on the other hand thanks to George R. R. Martin's best-selling books from the Song of Ice and Fire series, and J. K. Rowling's Harry Potter series.

Nowadays, fantasy is studied by many researchers in different disciplines: comparative literature, cultural studies, gender studies, medieval studies (as the majority of fantasy books and films has the medievalist form) and linguistics. Some linguistic studies are conducted not only by professionals, but also by fans from all over the world, for example the dictionary of Tolkien languages (http://www.alphadictionary.com/ directory/Languages/Artificial/Tolkien_Languages/) or lessons of Dothraki and Valyrian (http://www.dothraki.org/). Others are more specific and deal with one level of the language, such as metaphors, neologisms, etc. 
The paper aims to provide an analysis of the author's neologisms and their Polish and Slovene translations used in A Game of Thrones, which is the first book of Martin's fantasy series Songs of Ice and Fire.

According to the Oxford English Dictionary (2003: 1179), a neologism is "a newly coined word or expression that may be in the process of entering common use, but has not yet been accepted into mainstream language". Neologisms can apply both a new meaning and a new form, or just one of those elements (Satkiewicz 1969: 25).

The neologisms used in Songs of Ice and Fire have an authorial character, which means that they were created and applied for the first time by Martin, and before that they could not be seen in other sources.

All neologisms can be divided into semantic and lexical ones, depending on the process which occurs (usually word-formation devices such as affixation and compounding). Semantic neologisms are the result of the acquisition of a new meaning by an existing word, whereas lexical neologisms are newly formed words (by means of suffixes, prefixes, or by combining two or more existing words) or are borrowed from other languages. In Martin's Song of Ice and Fire most neologisms have the lexical character.

For many reasons neologisms might seem to be untranslatable, or at least very difficult to translate. As Cui (2012) states "untranslatability is a property of a text, or of any utterance, in one language, for which no equivalent text or utterance can be found in another language when translated". However one of the most frequent questions asked by translators and translation theoreticians is whether some terms are fully translatable while others fully untranslatable, or maybe everything is possible to translate, and the difficulty of the translation process depends on the translator's abilities, knowledge and the nature of the text itself.

According to Eco (2004), "translation is always a shift, not between two languages but between two cultures. A translator must take into account rules that are not strictly linguistic but, broadly speaking, cultural". This means that limited translatability might be caused by cultural differences which lead to cultural untranslatability, when "a situational feature, functionally relevant for the source language text, is completely absent from the culture of which the target language is a part" (Catford 1965: 93). In the case of neologisms used in fantasy novels the translation process is even more complicated as the translator has to focus not only on the cultures of both languages (despite creating new 
worlds, fantasy authors usually set the plot in a reality similar to their own culture), but also on the meaning of the new word. In most cases we can determine this by analysing the structure of the neologism and, obviously, by looking at the context in which the neologism was used. However, even if the translator understands the new word and its usage, another type of problem might occur - the translator has to create new words in the target language: "neologizmy stanowią zwykle problem tłumaczeniowy, gdyż po pierwsze nie da się sprawdzić ich znaczenia w słowniku języka wyjściowego ani rzecz jasna znaleźć ich docelowego ekwiwalentu w słowniku dwujęzycznym, a po drugie zastosowaniu neologizmu w tekście wyjściowym powinno w zasadzie odpowiadać użycie neologizmu $\mathrm{w}$ tekście docelowym, a zatem tłumacz musi zabawić się w słowotwórcę" (Hejwowski 2006: 112-113).

On the basis of that, it is necessary to emphasize that the process of the translation of neologisms consists in applying not only a new meaning, but also a new function which the new word will fulfil. The authors of Stylistyka polska, S. Skorupka nad H. Kurkowska (1959: 82), state that writers apply neologisms to their texts to impose their vision of the world on the reader.

Authorial neologisms occupy an important place in Martin's books. They embrace a wide layer of vocabulary: from obvious things and actions, to the names of new unreal objects, animals and personages. They are all newly created lexical units, and most of them will not become a unit in a dictionary. However, we can predict that they might be used by other fantasy authors.

For this analysis I used Martin's original novel A Game of Thrones and its Polish and Slovene translations: Gra o tron (translated by Paweł Kruk) and Igra prestolov (translated by Boštjan Gorenc).

When talking about the division of neologism translations, we can group them according to the technique chosen by the translator:

- borrowing,

- equivalency,

- creation of a new neologism.

The easiest technique is probably borrowing. It consists in applying an original neologism to the target language without changes or with small phonetic changes (for example transcription). Translators often apply this technique when translating proper names, especially toponyms (Tolkien's Mordor in Polish and Slovene translations was applied without 
changes, and Rowling's Hogwarts was changed to Hogwart in the Polish version of the Harry Potter novels). Some borrowed neologisms become frequently used words in the target language, for example zombie functions in Polish and Slovene. Borrowing is not only an easy choice, but also might have an additional meaning - foreign names seem to be more exotic than their equivalents derived from words which exist in the target language.

The second technique consists in finding an existing term in the vocabulary of the target language (e.g. Eng. dwarf, Pol. krasnolud, Slo. škrat). Sometimes this might be the hardest way of translating fantastic neologisms, as frequently the denotation does not exist in the target culture.

When deciding to apply the last technique, the translator has to invent a new word, e.g. Pratchett's Wee Free Men was translated into Polish as Wolni Ciut Ludzie. This way of translating neologisms is the most interesting from the linguistic point of view.

Kruk and Gorenc, the Polish and Slovene translators of George R. R. Martin's novel A Game of Thrones, both used all three techniques. The main difference between their translations is the frequency of application of a given technique. Kruk more often decided to borrow the original word, whereas Gorenc created his own neologisms, which can be seen in the table below, where a few important toponyms are presented. The words in bold are borrowed; equivalents are in italics; neologisms are underlined.

TABLE 1. Examples of toponyms and their translations

\begin{tabular}{|l|l|l|}
\hline \multicolumn{1}{|c|}{ English } & \multicolumn{1}{c|}{ Polish (Kruk) } & \multicolumn{1}{c|}{ Slovene (Gorenc) } \\
\hline Cape Wrath & Przylądek Gniewu & Rt gneva \\
\hline Dreadfort & Dreadfort & Grozotrdba \\
\hline Harrenhall & Harrenhall & $\underline{\text { Harrendvor }}$ \\
\hline Highgarden & Wysogród & Visoki vrt \\
\hline Karhold & Karhold & Katrdba \\
\hline Kingswood & Królewski Las & Kraljevi gozd \\
\hline Lannisport & Lannisport & Laniška luka \\
\hline Mander & Mander & Okljuk \\
\hline
\end{tabular}




\begin{tabular}{|l|l|l|}
\hline \multicolumn{1}{|c|}{ English } & \multicolumn{1}{c|}{ Polish (Kruk) } & \multicolumn{1}{c|}{ Slovene (Gorenc) } \\
\hline Mistwood & Deszczowy Las & Dežni gozd \\
\hline Moat Cailin & Fosa Cailin & Cailinski jarek \\
\hline Pyke & Pyke & Špik \\
\hline Riverrun & Riverrun & Rečnjava \\
\hline Seagard & Seagard & Morjevaht \\
\hline Starfall & Starfall & Utrinek \\
\hline Sunspear & Stoneczna włócznia & Sončna sulica \\
\hline Tarth & Tarth & Tarth \\
\hline The Reach & Reach & Dalja \\
\hline Torren's Square & Torrhen's Square & Torrhenov trg \\
\hline Widow's Watch & Wdowia Strażnica & Vdovska straža \\
\hline Winterfell & Winterfell & Zimišče \\
\hline Wolfswood & Wilczy Las & Volčja gošča \\
\hline
\end{tabular}

\section{CREATION OF A NEOLOGISM IN BOTH LANGUAGES}

For his novels George R.R. Martin created many neologisms. Most of them are toponyms or proper names, and only few refer to objects or animals.

One of the animals which is important for the plot is the direwolf. Martin created its name on the basis of the phrase 'dire wolf' (which means a large extinct wolf of the Pleistocene epoch). The adjective dire itself means 'serious' or 'urgent'. Knowing that, the reader should create a picture of a direwolf as a very big wolf. The Slovene translator, instead of an equivalent of dire, used the word krv, which means 'blood', so the whole word gained an additional meaning. The translator of the Polish version decided to use a different method to emphasize the size and importance of the animal - by adding the suffix - or $^{1}$ :

1 The suffix -or is very rarely used in Polish (gwiazdor), but the new construction should be clear for a Polish language speaker. 
(1) That's a direwolf. They grow larger than the other kind.

To jest wilkor. One są większe od wilków.

To je krvovolk. Zrastejo večji od navadnih volkov.

A suitable suffixation was also applied in the case of the adjective Valyrian. The Polish adjective was created by the stem valyr'- and a frequent suffix -ański, whereas the Slovene version was formed by the stem and the suffix -jski:

(2) The blade was Valyrian steel

Wykute z valyriańskiej stali

Rezilo je bilo iz valyrijskega jekla

The last example of the creation of a neologism in both languages is one of the names of Martin's heroine, Daenerys. The English adjective Stormborn was translated into Polish with a phrase, and into Slovene with a compound adjective:

(3) I am Daenerys Stormborn, Princess of Dragonstone, of the blood and seed of Aegon the Conqueror.

Jestem Daenerys, Zrodzona z Burzy, księżniczka Dragonstone, potomek Aegona Zdobywcy.

Jaz sem Daenerys, Nevihtorojena, princesa Zmajevega kamna iz krvi in semena Aegona Zavojevalca.

\section{CREATION OF A NEOLOGISM IN ONE OF THE LANGUAGES}

In the Polish and Slovene versions of Martin's novel we find many examples of unsimilarity in the translation of neologisms. In all cases the Slovene translator decided to create a neologism in the target language, whereas the Polish translator borrowed the original neologism without changing it. Examples of this process can be found in toponyms, proper names and objects: 
(4) blue eyes of the Tullys of Riverrun niebieskie oczy Tullych z Riverrun z modrimi očmi Tullyjevih iz Rečnjave ${ }^{2}$

(5) The Lannisters of Casterly Rock had come late to Robert's cause Ród Lannisterów z Casterly Rock przyłączył się do Roberta dość późno

Lannisterji z Livarske skale ${ }^{3}$ so se pozno priključili Robertovi stvari

(6) Daeren Targaryen was only fourteen when he conquered Dorne Daeren Targaryen miał tylko czternaście lat, kiedy podbił Dorne Daeren Targaryen je imel komaj štirinajst, ko je osvojil Dornijo ${ }^{4}$

(7) Jon Snow said quietly powiedział cicho Jon Snow je tiho rekel Jon Sneg ${ }^{5}(20)$

(8) The king might as easily have named one of his brothers, or even

\section{Littlefinger}

Twój mąż równie dobrze mógł się zwrócić do jednego ze swoich braci albo do Littlefingera.

Kralj bi zlahka imenoval enega od svojih bratov, ali celo Mezinčka (85)

An interesting process can be observed in the Slovene translations of three religious terms: sept (a place of cult), septon (a clergyman of the Faith of the Seven) and septa (clergyman of the Faith of the Seven). Boštjan Gorenc decided to change the word formation of all the words, and sept gained the feminine gender by the addition of the typical ending $-a$ (septa), whereas

\footnotetext{
2 The neologism Rečnjava was probably derived from two nouns: reka (river) and trdnjava (fortress).

3 The Slovene word livar means 'caster' and skala means 'rock'.

4 The suffix -ija is often used in Slovene to create names of countries: Slovenija, Bolgarija, Makedonija.

5 The noun sneg means 'snow'. It is interesting that the translator decided to translate this surname but left other surnames untranslated, e.g. Stark, which could have been rendered as Surov (literally 'raw', 'severe').
} 
septon and septa gained the common Slovene agentive endings -ik (septnik) and -ica (septnica):

(9) Catelyn had been (...) named in the rainbow of light that filled the sept of Riverrun.

Catelyn (...) otrzymała imię w blasku tęczy, której światło wypełniało Wielki Sept w Riverrun

Catelyn (...) dali ime v mavrici svetlobe, ki je polnila septo Rečnjave

(10) Anointed with the seven oils by the High Septon himself.

Namaszczony siedmioma olejami przez samego Wielkiego Septona.

$\mathrm{S}$ sedmimi olji ga je mazilil sam visoki septnik.

(11) Septa Mordane told their lady mother once

powiedziała kiedyś do jej matki septa Mordane

je njeni gospe materi nekoč rekla septnica Mordana

By changing the original neologisms the translator probably wanted to domesticate the new words. A similar goal was achieved in the case of the next word, which is used to describe a Maester - scholar, healer and scientist of the Seven Kingdoms, which was domesticated as moister in the Slovene translation:

(12) Maester Luwin will tell you they never lived at all.

Maester Luwin twierdzi nawet, że nigdy ich tu nie było.

Moister Luwin ti bo povedal

\section{BORROWING IN BOTH LANGUAGES}

In many cases both translators decided to leave the original version of a neologism. This usually happened when Martin's word formation was not clear: 
(13) The square brick towers of Pentos kontury przysadzistych ceglanych wież miasta Pentos Kvadratna opečnata stolpa Pentosa

(14) They had wandered since then, from Braavos to Myr, from Myr to Tyrosh, and on to Qohor and Volantis and Lys, never staying long in any one place.

Od tamtej pory wciąż wędrowali, z Braavos do Myr, z Myr do Tyrosh i dalej do Qohor, Volantis i Lys, nigdzie nie zatrzymywali się na długo

Od takrat sta tavala, iz Braavosa v Myr, iz Myra v Tyrosh in naprej $\mathrm{v}$ Qohor in Volantis in Lys, ter se nikjer nista ustavila

(15) A hundred thousand men ride in his khalasar

W jego khalasar jeździ sto tysięcy ludzi

Sto tisoč ljudi jezdi v njegovem khalasarju

(16) what a handsome man the khal was

jak przystojny jest sam khal

kakšen čeden moški je khal

\section{EQUIVALENCY}

The last technique consists in finding an existing term in the vocabulary of the target language. In most cases this solution was used when translating whole phrases or compound words:

(17) his sword sworn to Mance Rayder, the King-beyond-the-Wall zaprzysiężony Mance'owi Ryderowi, Królowi-poza-Murem svoj meč prisegel Manceu Rayderju, kralju onkraj zidu

(18) Catelyn had never liked this godswood.

Catelyn nigdy nie lubiła tego gaju bogów.

Catelyn ni nikoli marala tega božjega gozdiča. 
(19) when they fled King's Landing to escape the advancing armies of the Usurper

opuścili Królewską Przystań uciekając przed nadciągającymi wojskami Uzurpatora

ko so pobegnili iz Kraljevega pristanka, da bi ušli napredujoši vojski Prisvojitelja

(20) She had been born on Dragonstone nine moons after their flight w czasie ucieczki nocą na Smoczą Wyspę Polnočni beg na Zmajev kamen

(21) he wore the spiked bronze cap of the Unsullied miał spiczastą czapeczkę z brązu Niesplamionych nosil je bronasto pokrivalo Brezmadežnih

(22) the Lord of Storm's End had been

Lord Końca Burzy był wtedy je bil gospod Neurjevega konca

(23) staring down (...) while the Kingslayer opened Father's throat with a golden sword

patrzyły (...) jak Królobójca złotym mieczem otwiera gardło ich ojca zrejo (...) ko Kraljemorec z zlatim mečem odpira očetov vrat

\section{CONCLUSION}

It is well known that nowadays the fantasy genre is very popular. When writing, the author creates names for objects and phenomena of the imaginary world. Translators might have some problems translating these authorial neologisms.

Kruk and Gorenc, the Polish and Slovene translators of George R. R. Martin's novel A Game of Thrones, both used the same translation 
techniques: borrowing, equivalency and the creation of target neologisms. The main difference between their translations is the frequency of application of a given technique. Kruk more often decided to borrow the original word, whereas Gorenc created his own neologisms.

\section{REFERENCES}

Catford, J.C. 1965. Linguistic Theory of Translation. London.

Eco, U. 2004. Mouse or Rat: Translation as Negotiation. London.

Hejwowski, K. 2006. Kognitywno-komunikacyjna teoria przekładu. Warszawa.

Jingjing, C. 2012. "Untranslatability and the Method of Compensation, Theory and Practice", Language Studies, Vol. 2, No. 4, 826-830.

Kurkowska, H., Skorupka S. 1959. Stylistyka polska: zarys. Warszawa.

Martin, G. R.R. 2010. A game of thrones. Kindle edition.

Martin, G. R.R. 2011. Gra o tron, electronic version.

Martin, G. R.R. 2012. Igra prestolov. Ljubljana.

Oxford Dictionary of English. 2003. ed. by Catherine Soanes, Angus Stevenson. Oxford.

Satkiewicz, H. 1969. Produktywne typy słowotwórcze wspótczesnego języka ogólnopolskiego. Warszawa.

Yolen, J. 2001. "Introduction". In M. H. Greenberg (ed.) After the King: Stories in Honor of J.R.R. Tolkien, vii-viii.

\section{AUTHOR'S NEOLOGISMS \\ IN GEORGE R. R. MARTIN'S A GAME OF THRONES AND THEIR POLISH AND SLOVENE TRANSLATIONS}

\section{Summary}

The paper aims to provide an analysis of the author's neologisms used in A Game of Thrones, which is the first book of Martin's fantasy series Songs of Ice and Fire. In the first part the paper identifies the sources of the author's lexical neologisms (e.g. direwolf, septon, or proper names). The second part focuses on the methods used for neologism translation in the Polish and Slovene versions of the novel (translations by Paweł Kruk and Boštjan Gorenc), and finds differences between the two translations. The paper describes translation techniques such as borrowing, equivalency, and the creation of a neologism.

Key words: neologism, fantasy, translation, Polish, Slovene 


\section{NEOLOGIZMY AUTORSKIE \\ W POWIEŚCI GRA O TRON GEORGE'A R. R. MARTINA ORAZ JEJ POLSKIM I SLOWEŃSKIM TłUMACZENIU}

\section{Streszczenie}

Artykuł stanowi próbę analizy neologizmów autorskich użytych w Grze o tron, czyli pierwszym tomie sagi Pieśni lodu i ognia George'a R.R. Martina. W pierwszej części zostają przedstawione źródła neologizmów (np. direwolf, septon oraz nazwy własne). Druga część jest porównaniem metod, jakimi posługiwali się tłumacze polskiej i słoweńskiej wersji powieści (Paweł Kruk i Boštjan Gorenc).

Słowa kluczowe: neologizm, fantastyka, tłumaczenie, język polski, język słoweński 